\title{
Field Application of Microbial Self-Healing Cement Slurry in Chunguang 17-14 Well
}

\author{
Lixia Li ${ }^{1}$, Tianle Liu ${ }^{1, *}$, Guosheng Jiang ${ }^{1}$, Changliang Fang ${ }^{1}$, Jiaxin Sun ${ }^{1}$, Shaojun Zheng ${ }^{1}$, Haodong Liu ${ }^{1}$, \\ Ekaterina Leusheva ${ }^{2}$, Valentin Morenov ${ }^{2}$ and Nikolai Nikolaev ${ }^{2}$ \\ 1 Faculty of Engineering, China University of Geosciences, Wuhan 430074, China; \\ 1lx1039304620@cug.edu.cn (L.L.); jianggs@cug.edu.cn (G.J.); fangcl@cug.edu.cn (C.F.); \\ jiaxinsun@cug.edu.cn (J.S.); sjzheng212@cug.edu.cn (S.Z.); gcxylhd@cug.edu.cn (H.L.) \\ 2 Department of Petroleum Engineering, Saint-Petersburg Mining University, 199106 Saint Petersburg, Russia; \\ Leusheva_EL@pers.spmi.ru (E.L.); morenov@spmi.ru (V.M.); nikinik@mail.ru (N.N.) \\ * Correspondence: liutianle2008@163.com; Tel.: +86-15327185363
}

Citation: Li, L.; Liu, T.; Jiang, G.; Fang, C.; Sun, J.; Zheng, S.; Liu, H.; Leusheva, E.; Morenov, V.; Nikolaev, N. Field Application of Microbial Self-Healing Cement Slurry in Chunguang 17-14 Well. Energies 2021, 14, 1544. https://doi.org/10.3390/ en14061544

Academic Editor: F. Pacheco Torgal

Received: 21 February 2021

Accepted: 9 March 2021

Published: 11 March 2021

Publisher's Note: MDPI stays neutral with regard to jurisdictional claims in published maps and institutional affiliations.

Copyright: (c) 2021 by the authors. Licensee MDPI, Basel, Switzerland. This article is an open access article distributed under the terms and conditions of the Creative Commons Attribution (CC BY) license (https:// creativecommons.org/licenses/by/ $4.0 /)$.

\begin{abstract}
Due to the inappropriate treatment of dairy wastewater, which can easily cause underground water pollution, there is an increasing need for a novel approach to reuse dairy wastewater. The technology of microbially induced calcium carbonate precipitation with environmentally friendly characteristics and high efficiency has been widely used for underground infrastructure remediation. However, there is a lack of in-depth research on the application of this technology under extreme underground environments, such as the borehole of oil wells with high temperature, high pressure, alkaline, and aerobic conditions. In addition, to reduce the cost of this technology when applied on a large scale, we adopted dairy wastewater to cultivate bacteria. Then, we put the bacterial solution into cement slurry in the borehole to improve the cementing quality. In this paper, the rheology properties, mechanical strength, permeability, porosity, and pore distribution of microbial cementing slurry were studied. Moreover, we applied this microbial cement slurry in the Chunguang 17-14 well of China, and the sealing channeling ability of cement sheath on site was evaluated. The results showed that dairy wastewater could serve as an alternative medium to provide nutrients and energy for the growth of bacteria with low cost. Additionally, the microbial cement slurry exhibited a good right-angle thickening performance and high mechanical strength. The field application displayed an anti-gas channeling ability after microbial remediation. The application of dairy wastewater incubated bacteria to cement slurry not only provides an alternative method for the reuse of dairy wastewater but is also conducive to prolonging the lifespan of oil wells.
\end{abstract}

Keywords: microbially induced calcium carbonate precipitations; self-healing properties; cement slurry; field application

\section{Introduction}

With the development of technology and living levels, the amount of dairy wastewater is increasing at the same time [1]. The annual treatment cost involving electricity, medicine, labor, and maintenance accounts for about $5 \%$ of the production cost [2]. As is well known, dairy wastewater causes underground water pollution and ecological destruction if it is disposed without appropriate treatment $[3,4]$. In recent years, bacterial degradation has been reported to be a more popular way to alleviate underground water pollution. However, there is a lack of investigations on the reuse of dairy wastewater-incubated bacteria, thus resulting in a high loss of nutrients.

Additionally, cement is a common material to be used underground, such as in the wellbore, a typical extreme underground environment with a high cost of artificial maintenance for cracking [5-7]. The development of micropores in the internal structure of cement stone and low early strength could result in microfractures and crack propagation [8]; therefore, it is often encountered with the channeling of oil, gas, and water layers $[9,10]$. Much 
work has been conducted for the improvement of the properties of cement slurry with chemical additives [11]. However, considering the risk of environmental pollution caused by chemical admixtures, there is an urgent need for a more environmentally friendly, efficient, and economical method to alternate chemical additives [12]. Moreover, carbon dioxide emissions are produced during the production of cement [13]. In recent years, a new environmental technology based on microbially induced calcium carbonate precipitation (MICP) has been widely used in the field of geological engineering, such as limestone remediation [14,15], soil consolidation [16,17], foreshore slopes stabilization [18], rock fracture repairing [19], concrete healing [20-34], and leakage remediation underground [35,36]. All these investigations indicate the potential of the application of bacterial spores as a self-healing agent in cement slurry under an extreme environment. As is well known, underground conditions are usually high temperature, high pressure, hypoxic, and alkaline, such as in the wellbore, a typical underground environment that is extremely rigorous for the survival of microorganisms. However, most previous research has been focused on the surface crack repairing and self-healing of concrete in the atmosphere and room temperature. Additionally, the cost of this MICP technology is mainly derived from media which limit its application on site. Achal [29] proposed that dairy wastewater can be an alternative medium to cultivate bacteria in the laboratory, but the survival rate of bacteria in underground conditions, such as high temperature and high pressure, has not been discussed to date.

In this paper, we applied microbial cement slurry in the Chunguang 17-14 well that locates in the western Junggar basin uplift of China. The buried depth of the heavy oil reservoir in the Chunguang oilfield is $900-1100 \mathrm{~m}$, and the average thickness of the reservoir is $3.1 \mathrm{~m}$. The interlayer is thin, and the longitudinal oil-water relationship is complex. The viscosity of degassed crude oil at the reservoir temperature is between $34,542.95 \mathrm{mPa} \cdot \mathrm{s}$ and $61,051.2 \mathrm{mPa} \cdot \mathrm{s}$. The crude oil is extra-heavy and has a high viscosity, which is usually developed by thermal exploitation. Figure 1a exhibits the results of a neutron logging test at a depth of 960-1004 $\mathrm{m}$ in the Chunguang 17-14 well, which indicated that the channeling problems due to the poor quality of cementation outside the pipe occurred in the section of 850-1150 m depth of the wellbore. As is well known, cementation quality directly determines the lifespan and recovery of oil and gas. Figure $1 \mathrm{~b}$ shows the curve of temperature and pressure in the sediments maintained in a range of $45.8-48.1^{\circ} \mathrm{C}$ and 6.049-6.141 $\mathrm{MPa}$, respectively. It is considered as an extreme environment for the survival of most bacteria, especially in comprehensive conditions with high temperature, high pressure, low oxygen concentration, and high alkaline. Therefore, we applied microbial cement slurry with dairy wastewater in the channeling section of the Chunguang 17-14 well on-site to investigate its healing ability.

Meanwhile, to promote the technology of MICP in underground engineering on a large scale in an environmentally friendly and economical way, the growth of bacteria and urease activity in dairy wastewater, as well as the viability of bacteria in the cement slurry, were compared to standard media and nutrient broth media under a simulated underground environment. Moreover, we investigated the performance of well cement slurry with bacterial treatment, including the thickening time, mechanical strength, permeability, and porosity, in the laboratory. The fact that microbial cement slurry with dairy wastewater can be successfully applied to the wellbore with an extreme underground environment indicates a bright prospect for the technology of microbially induced calcium carbonate in engineering. 

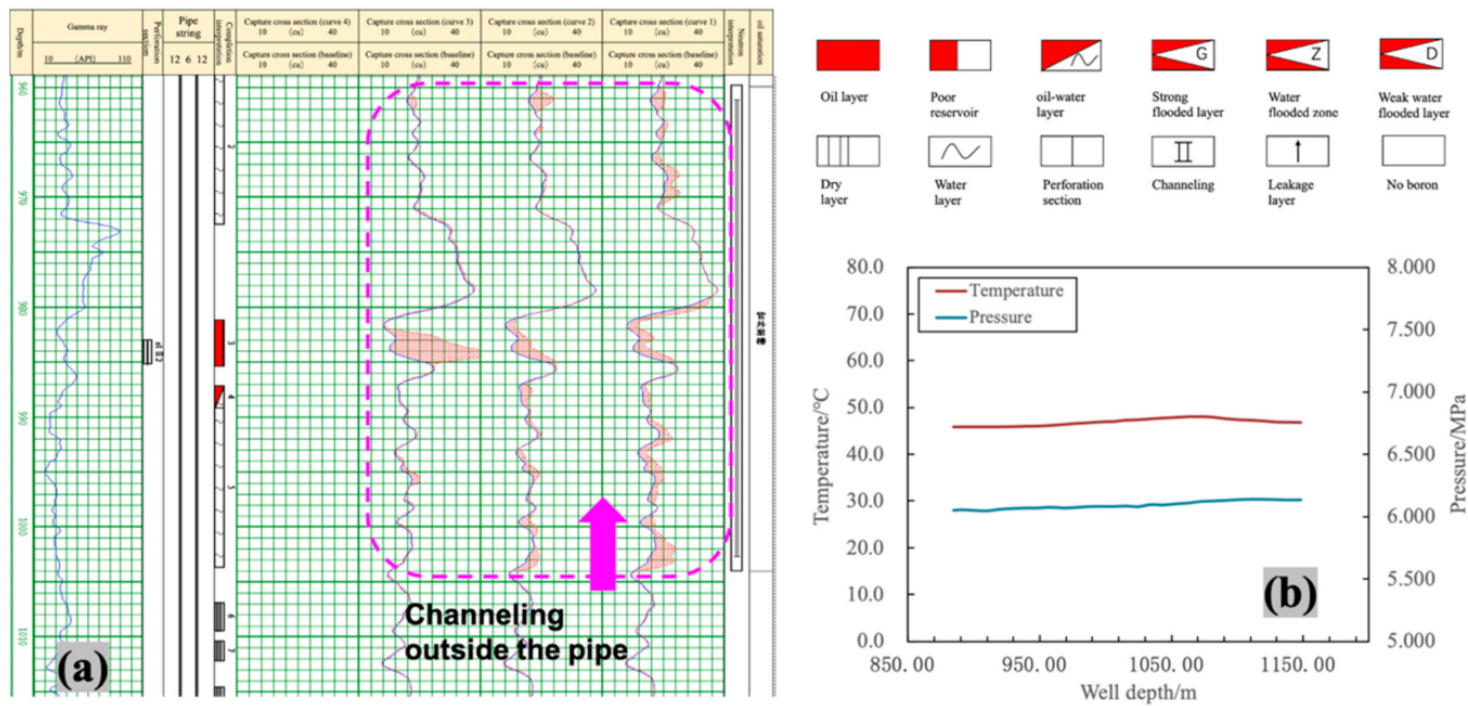

Figure 1. (a) Neutron logging in Chunguang 17-14 well before biotreatment; (b) the temperature and pressure in the section of cementing problem.

\section{Materials and Methods}

\subsection{Microorganism and Medium}

In this paper, we adopted mutated bacteria which were domesticated from a typical urease-producing microorganism named sporosarcina pasteurii (ATCC11859), and the initial bacteria were purchased from the Chinese Microbial Network. The mutated bacteria could survive at $70{ }^{\circ} \mathrm{C}$ and keep high enzymatic activity in an alkaline and anoxic environment for a long time. The following experiments and tests were based on mutated bacteria. The components of dairy wastewater include $16.5 \mathrm{~g} / \mathrm{L}$ lactose, $12.6 \mathrm{~g} / \mathrm{L}$ protein, $2.6 \mathrm{~g} / \mathrm{L}$ fat, $350 \mathrm{mg} / \mathrm{L}$ calcium, and $8 \mathrm{~g} / \mathrm{L} \mathrm{NaCl}$, which were resourced from the dairy factory in Wuhan, China. After collecting the dairy wastewater from the factory, the coarse filtration treatment was carried out first to remove the insoluble bulky matrix in the dairy wastewater, such as hair lumps. Then, we put it in the disperser and stirred it at high speed to promote the dissolution of suspended organic matter. Next, the initial dairy wastewater culture medium was obtained after fine filtration once again. The content of the component in the initial dairy wastewater culture medium was tested at the same time. Finally, the initial dairy wastewater was sterilized, cooled, and then inoculated with microorganisms that can produce urease for further research. The standard medium (15 g/L casein peptone, $5 \mathrm{~g} / \mathrm{L}$ soy peptone, and $5 \mathrm{~g} / \mathrm{L} \mathrm{NaCl})$ and nutrient broth medium $(10 \mathrm{~g} / \mathrm{L}$ casein peptone, $3 \mathrm{~g} / \mathrm{L}$ beef extract, and $5 \mathrm{~g} / \mathrm{L} \mathrm{NaCl}$ ) purchased from Beijing Aoboxing Biotechnology Co. LTD were compared to dairy wastewater in this paper. Additionally, the urea played an important role as a trigger for the metabolic processes of this microorganism; thus, $20 \mathrm{~g} / \mathrm{L}$ urea was added into these three kinds of media, respectively, to provide carbon resources.

\subsection{Calcium Resources}

In the manufacture of microbial cement slurry, the calcium ions were added by calcium chloride encapsulation. Assuming that carbonate generated from the decomposition of urea can react with calcium ions completely and considering the effect of encapsulation on the property of well cement slurry, the dosage of calcium chloride encapsulation in G-class well cement was suggested at 3 3.5\%. The calcium chloride was encapsulated by polyvinyl alcohol (PVA), and the content of calcium chloride in the encapsulation was 75.45 82.5\%. Figure 2 exhibits that the initial release time of calcium chloride was $255 \mathrm{~min}$, which meets the requirement of microbial cementation operation. 


\subsection{Cultivation and Growth Test}

The optical density value at the wavelength of $600 \mathrm{~nm}$ (OD600) is widely used to characterize microbial growth. The mutated bacteria were cultivated in three media, respectively, at $50{ }^{\circ} \mathrm{C}, 6.5 \mathrm{MPa}, \mathrm{pH} 13$, and $1.1 \%$ oxygen concentration for $24 \mathrm{~h}$. In this experiment, an ultraviolet-visible spectrophotometer (756CRT, Shanghai Yidian Analytical Instrument Co., Ltd., Shanghai, China.) was used to measure the OD600 value at intervals.

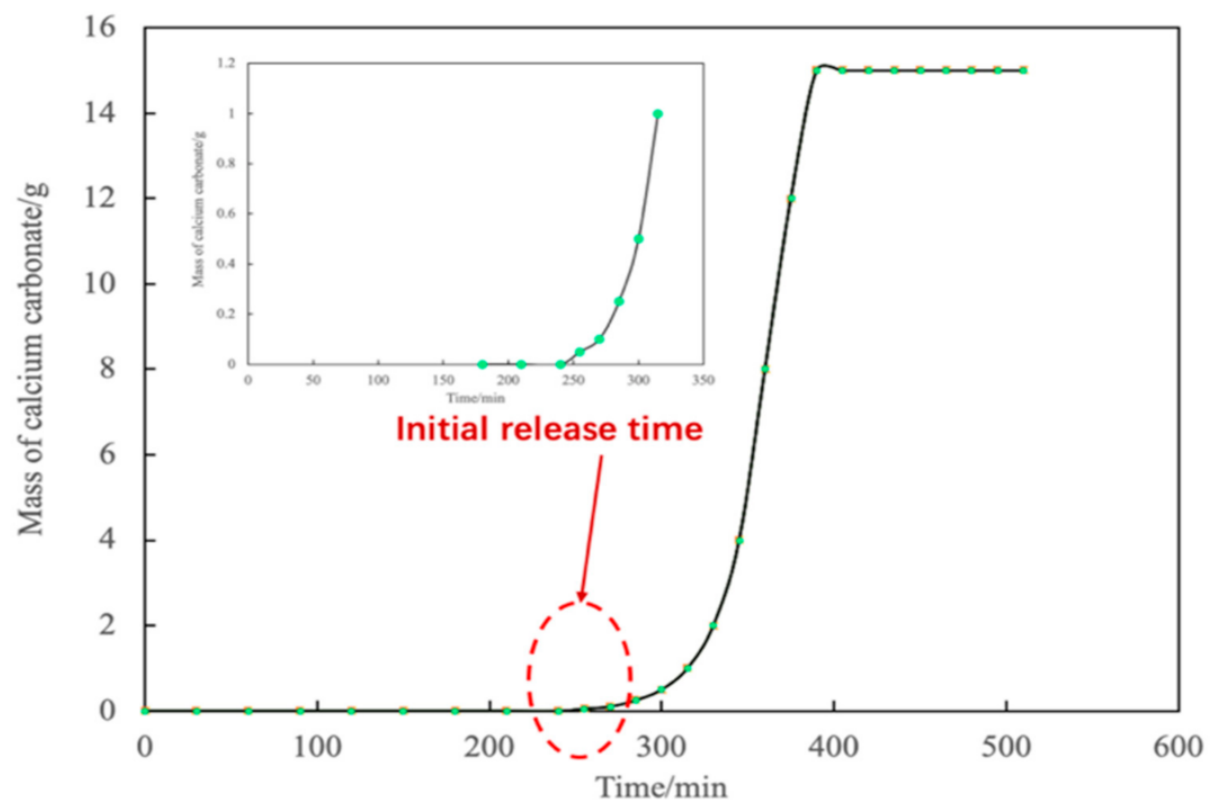

Figure 2. The release property of calcium chloride encapsulation.

Conductivity was recorded to measure the urease activity. The hydrolysis of urea liberates ionic products from non-ionic substrates according to the following Equation (1). First, $1.5 \mathrm{~mL}$ of bacterial solution was mixed into the $13.5 \mathrm{~mL}$ of $1.6 \mathrm{M}$ urea solution. At room temperature, the change of conductivity within $5 \mathrm{~min}$ was monitored by the conductivity meter, and the average change of conductivity per minute $(\mathrm{mS} / \mathrm{min})$ was obtained. According to the empirical value obtained by Whiffin [37], a change of conductivity of $1 \mathrm{~ms} / \mathrm{min}$ corresponds to the amount of urea hydrolysis of $11 \mathrm{mM}$ urea hydrogenated per minute. The average change of conductivity per minute $(\mathrm{mS} / \mathrm{min})$ can be converted into the amount of urea hydrolyzed by urease per unit of time (mM urea) and multiplied by the dilution multiple 10. This value is used to express urease activity. Therefore, specific urease activity can be obtained according to the following Equation (2):

$$
\mathrm{H}_{2} \mathrm{~N}-\mathrm{CO}-\mathrm{NH}_{2}+2 \mathrm{H}_{2} \mathrm{O} \stackrel{\text { urease }}{\rightarrow} 2 \mathrm{NH}_{4}^{+}+\mathrm{CO}_{3}^{2-}
$$

$$
\begin{gathered}
\text { Specific Urease Activity }\left(m M \text { urea hydrolysed } \cdot \text { min }^{-1} \cdot O D^{-1}\right) \\
=\frac{\text { Urease Activity }\left(m M \text { urea hydrolysed } \cdot m^{-1}\right)}{\text { Biomass }\left(O D_{600}\right)}
\end{gathered}
$$

Additionally, we also tested the changes of BOD and COD of dairy wastewater after incubating bacteria by a BOD detector (typed GY-B780, manufactured by Shanghai Cong Yi Electronics and Technology Co., Ltd., Shanghai, China.) and COD fast detector (typed GYK200, manufactured by Shanghai Cong Yi Electronics and Technology Co., Ltd., Shanghai, China.), respectively.

\subsection{Preparation and Curing of Cement Stone}

Microbial cement slurry was prepared in a water-to-cement weight ratio of 0.44 , the water was replaced by the bacterial solution, and the addition of calcium chloride 
encapsulation was 3\%. In this paper, the G-class oil well cement without adding bacterial solution was regarded as the control group. First, all the materials were mixed at a speed of $4000 \mathrm{rps} / \mathrm{min}$. Then, the cement paste was poured into molds with dimensions of $40 \times 40 \times 40 \mathrm{~mm}, 40 \times 40 \times 160 \mathrm{~mm}$, and $\varnothing 25 \times 100 \mathrm{~mm}$ according to the standards of the American Petroleum Institute (API); the rheology property was tested at the same time. When the cement slurry began to set, the specimens were cured in a water bath kettle at $50{ }^{\circ} \mathrm{C}, 6.5 \mathrm{MPa}$. The specimens were not removed from the kettle until the strength, permeability, and porosity of cement stone were tested. The simulated cultivation and curing environment in the following experiments in the laboratory was based on the wellbore conditions.

\subsection{Rheology Property of Cement Slurry}

The cement slump was measured by a slump tester (TLD-A, manufactured by Tianjin Yaxing Automation Experimental Instrument Factory, Tianjin, China.) according to the standard of GB/T50080-2002. The thickening time at 30 and 100Bc was tested, respectively, by a high-temperature and high-pressure (HTHP) consistometer (NZCJ, manufactured by Tianjin Nithons Technology Co., Ltd.) at $50{ }^{\circ} \mathrm{C}, 6.5 \mathrm{MPa}$. The fluid loss of the cementing slurry was evaluated by a fluid loss testing instrument (NJSQ, manufactured by Tianjin Nithons Technology Co., Ltd.) according to the API standards. The anti-gas channeling performance of cement slurry can be determined by the performance numeric of cement slurry (SPN). The calculation formula of SPN is Equation (3):

$$
S P N=F L(A P I) \times \frac{\sqrt{t_{100 B c}}-\sqrt{t_{30 B c}}}{\sqrt{30}}
$$

FL(API): API fluid loss of cement slurry, $\mathrm{mL}$;

$t 100 B c$ : thickening time at $100 \mathrm{Bc}$ of cement slurry, min;

$t 30 B c$ : thickening time at 30Bc of cement slurry, min.

The criteria for the determination of the anti-gas channeling performance of cement slurry are the following: SPN is in $0-3$, the anti-gas channeling performance is perfect; SPN is in 3-6, the anti-gas channeling performance is medium; SPN is beyond 6, the anti-gas channeling performance is poor.

\subsection{Compressive Strength}

The compressive strength and flexural strength of the cement specimens after curing for 3,7 , and 28 days were measured using an automatic compression and bending mechanical tester (COMPTEST 3000, manufactured by Jinan Zhongchuang, Co. Ltd., Shandong, China) based on the API standard, respectively. All trials were conducted in three parallel runs and then averaged.

\subsection{Permeability and Porosity}

The permeability of the cement stone with curing age was tested by combined porosity and permeability equipment (manufactured by Jiangsu Kedi Co., Ltd., China) based on Darcy law in the method of gas injection with a constant flow. The demission of specimens to the porosity and permeability was $\varnothing 25 \times 100 \mathrm{~mm}$. Then, the change of pore distribution of specimens at 3 days was tested by X-ray micro-CT (Nano Voxel-3000, manufactured by Sanying Precision Instruments Co., Ltd., China). The beam energy was $150 \mathrm{kV}$. The samples were put on the rotation stage with a rotated speed in $1^{\circ}$ per steps. After the scan in a circle of $360^{\circ}, 1440$ projections were recorded by the 16-bit $1920 \times 1536$-pixel flat panel detector, and the pixel size was $13.93 \mu \mathrm{m}$. Then, the images were reconstructed and analyzed.

\subsection{Viability of Bacteria in Cement Stone}

After the mechanical strength test, the fragments of cement stone were collected and pulverized. The viability of bacteria in cement stone was tested by the most probable number (MPN) technique, as shown in the literature of Clarke and Owens [38]. The growth 
of positive bacteria correlated with the turbidity of the medium. Therefore, the viable bacteria can be estimated by the turbidity test.

\subsection{Morphological Characteristics}

The fragments of cement stone were dried in an oven for $24 \mathrm{~h}$ and then cooled; the morphological characteristics of precipitations in cement specimens were observed under Scanning Electron Microscopy (Phenom G6 Pro, manufactured by Phenom Scientific Instrument Co., Ltd., Eindhoven, Netherlands) 500 and 5000 times, respectively. The composition of crystals in cement stone was analyzed by Energy Dispersive Spectrometer (EDS). The precipitations in liquid medium were finely ground with an agate bowl until all passed through the 200 target sieves (the mesh size is $75 \mu \mathrm{m}$ ), and then it was put into the dryer for $24 \mathrm{~h}$. The phase composition of the samples was analyzed by a D8 fullautomatic XRD instrument made in Brooke, Germany. The scanning rate was $0.15 \mathrm{~s} / \mathrm{step}$, and $2 \theta=10^{\circ} \sim 90^{\circ}$.

\section{Results and Discussion}

\subsection{Effects of the Medium on the Growth of Bacteria}

As shown in Figure 3a, the growth of bacteria in dairy waster was relatively close to the bacteria in standard medium and nutrient broth medium. The concentration of bacteria in dairy wastewater in the stabilization period was approximately similar to the other two media, and there was no obvious difference among these three media. It is worth mentioning that the growth of bacteria in the dairy wastewater medium was relatively rapid and vigorous, which could shorten the time of application. Figure $3 \mathrm{~b}$ shows that the domesticated bacteria could keep high urease activity, which is paid much more attention in practical engineering applications, and a similar trend was observed with the growth curve of bacteria. However, the specific urease activity of the bacterial solution was the inverse, as shown in Figure 3c, and it was decreased with the increase in bacterial concentration. With the increase in time and bacterial concentration, the activity of urease in bacterial solution was increased, and the ability of catalyzing urea hydrolysis was also increased. According to the analysis, the specific urease activity of bacteria is mainly affected by the concentration of substances in the culture medium. From the calculation formula (2), it can be seen that the concentration of microorganisms gradually increased, but the change rate of the total urease activity of bacteria was much slower than the OD600 value. Therefore, the specific urease activity was decreased.

The results showed that dairy wastewater could provide the nutrients for the metabolism of bacteria at a low cost; see Table 1. Compared with the standard medium and nutrient broth medium, the preparation of microbial cementing slurry with the same volume of dairy wastewater needs to consume more dairy wastewater. However, dairy wastewater has a wide range of sources, so there is no cost. Additionally, we considered the additional cost of dairy wastewater pretreatment. The comprehensive cost was calculated, and the results showed that the cost of using dairy wastewater to cultivate microorganisms and prepare microbial cementing slurry was lower, which is more suitable for large-scale application.

\subsection{Changes of COD and BOD in Dairy Wastewater}

Table 2 exhibits that the COD and BOD of dairy wastewater were significantly decreased after the incubation of bacteria. As is well known, protein, fat, and lactose in dairy wastewater are the main reasons for high COD and BOD. The protein, fat, lactose, and other nutrients in dairy wastewater could be used as carbon and nitrogen sources by microorganisms. Therefore, the COD and BOD in dairy wastewater were effectively reduced because of the metabolism of bacteria. Additionally, we found that the value of $\mathrm{pH}$ after the incubation of bacteria was increased. It is believed that the nitrogen sources including protein and urea were hydrolyzed into $\mathrm{NH}_{4}{ }^{+}$and $\mathrm{CO}_{3}{ }^{2-}$ by the mutant bacteria, which resulted in the accumulation of $\mathrm{OH}^{-}$in the microenvironment eventually. They were below the direct emission standard of dairy wastewater. Therefore, it is an environmentally 
friendly method to prevent the underground water from being polluted by the reuse of dairy wastewater by the degradation of bacteria.
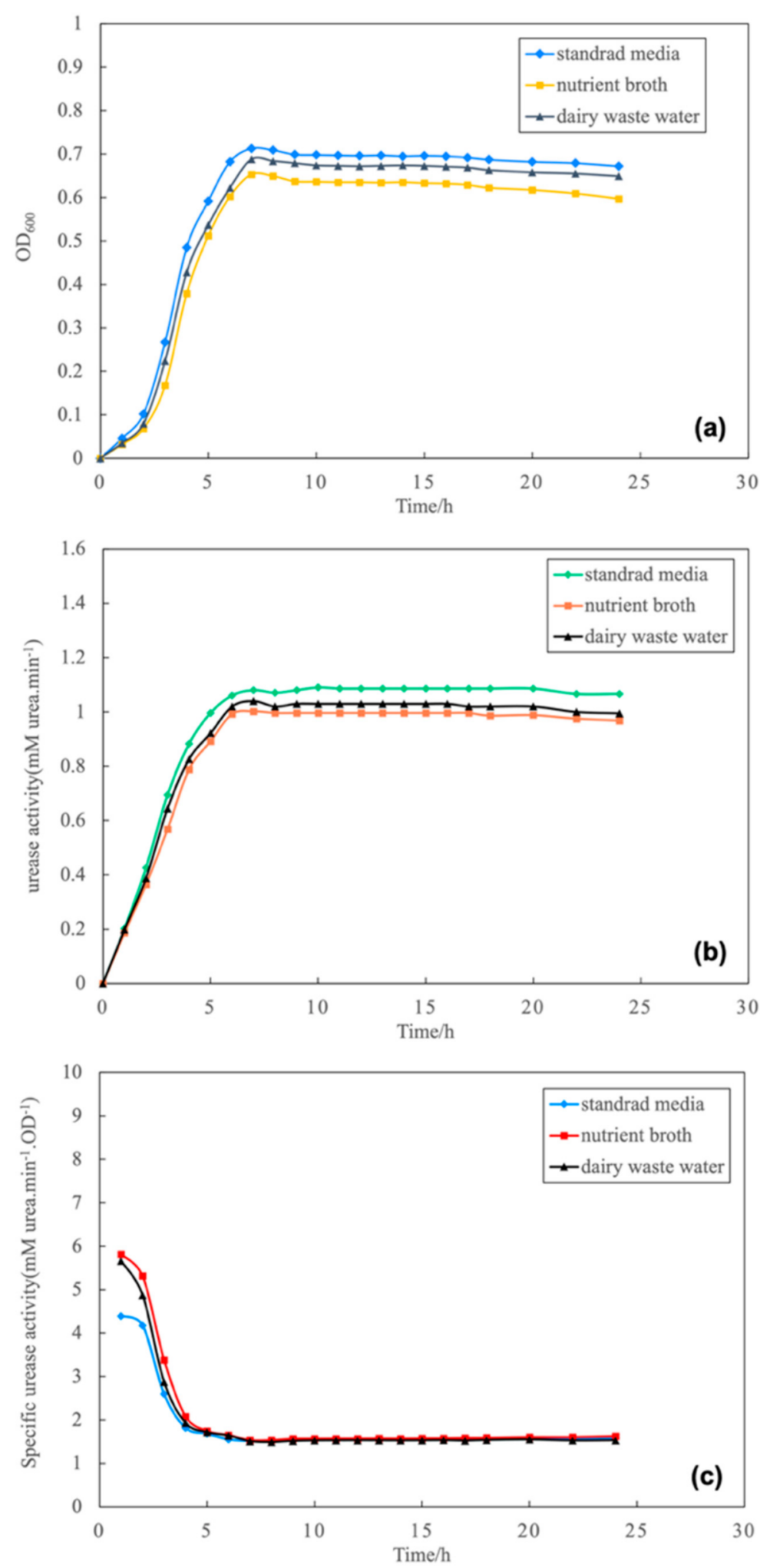

Figure 3. (a) Growth curve of bacteria in different media; (b) urease activity of bacteria in different media with time; (c) specific urease activity of bacteria in different media with time. 
Table 1. The comparison of cost and effect of different media on well cement slurry.

\begin{tabular}{cccccc}
\hline Media & $\begin{array}{c}\text { Mass of Media/1 } \\
\text { kg G-Cement }\end{array}$ & $\begin{array}{c}\text { Media } \\
\text { (USD/kg) }\end{array}$ & $\begin{array}{c}\text { Additional Cost } \\
\text { (USD / } \mathbf{k g})\end{array}$ & $\begin{array}{c}\text { G (USD } \\
/ \mathbf{k g})\end{array}$ & $\begin{array}{c}\text { Total Cost } \\
\text { (USD /kg) }\end{array}$ \\
\hline $\mathrm{SM}+\mathrm{G}$ & 0.006 & 40 & 0 & 0.09 & 40.09 \\
$\mathrm{NB}+\mathrm{G}$ & 0.018 & 20 & 0 & 0.09 & 20.09 \\
$\mathrm{DW}+\mathrm{G}$ & 0.5 & 0.0002 & 0.0003 & 0.09 & 0.0913 \\
\hline
\end{tabular}

Note: Additional cost means cost of pre-treatment for media before cultivation and transportation. Prices of products and costs were calculated by the market value.

Table 2. Changes of COD, BOD, and $\mathrm{pH}$ in dairy wastewater.

\begin{tabular}{cccc}
\hline & COD $(\mathrm{mg} / \mathrm{L})$ & BOD $(\mathrm{mg} / \mathrm{L})$ & pH \\
\hline Before incubation & 2200 & 1209 & $5-6$ \\
Emission standard & 150 & 30 & $6-9$ \\
After incubation & 94 & 15 & $8-9$ \\
\hline
\end{tabular}

The metabolism process of bacteria with dairy wastewater is displayed in Figure 4. First, nutrients, such as protein, fat, and lactose, in dairy wastewater were decomposed into small molecular substances by a special enzyme, and then they were transported through the cytoderm into the cytoplasm of bacteria. The smaller molecules were absorbed and utilized to synthesize new substrates, such as macromolecules and other cell components. Urease was the product of metabolism in the cytoplasm, and it was transported to the outside of the cell wall through the function of the compatriot. In this process of catabolism, the energy was generated, and it was used to synthesize proteins such as urease and other macromolecular substances needed by microbial cells. Additionally, they were used to synthesize metabolic by-products, such as acids, $\mathrm{CO}_{2}$, and $\mathrm{NH}_{3}$. Moreover, the energy was produced for the respiration, motility, and transportation of nutrients. Therefore, the more nutrients were in media, the more energy and urease were produced at the same time.

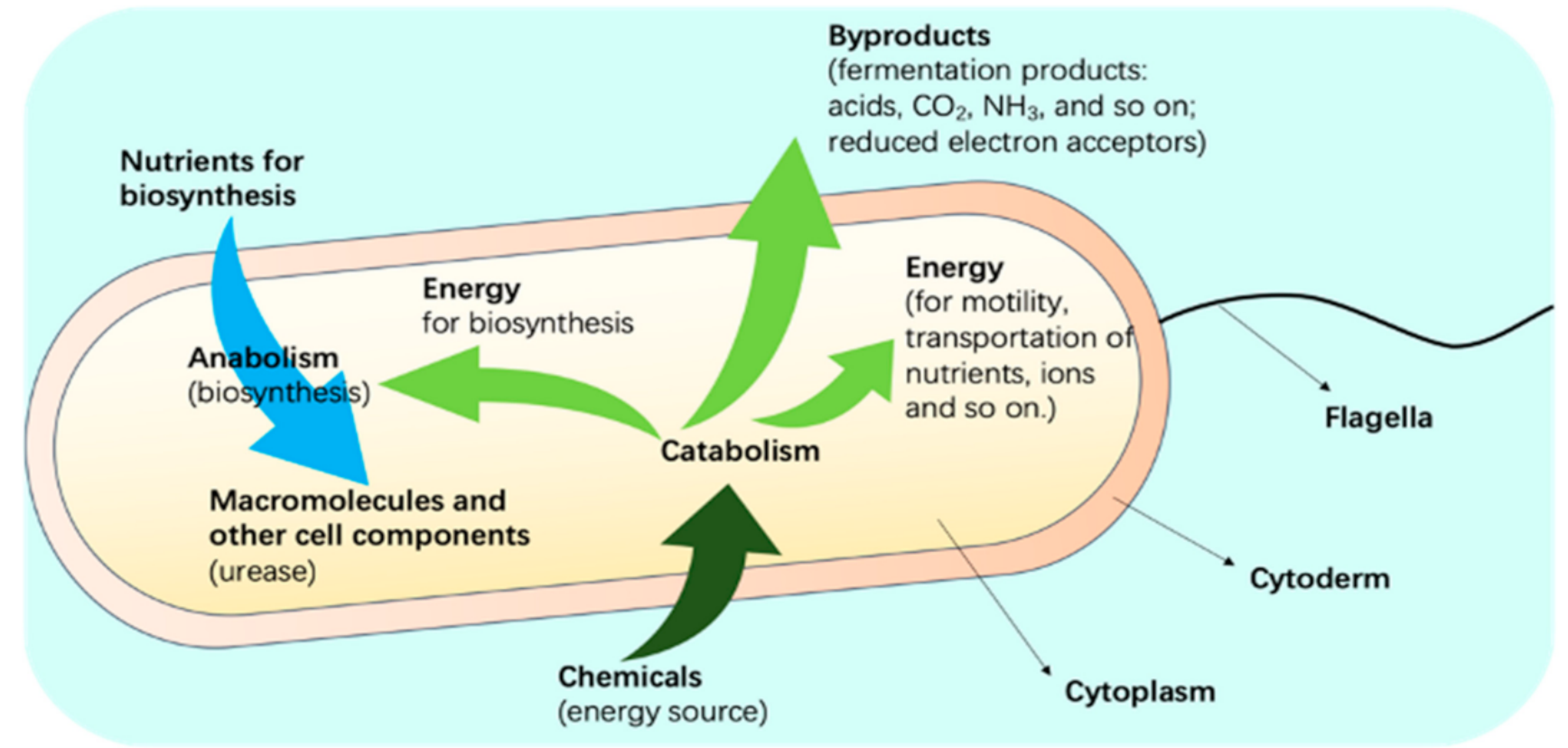

Figure 4. The metabolic process of microorganisms utilizing dairy wastewater.

\subsection{Rheology Property of Microbial Cement Slurry}

We found that the slump of microbial cement slurry with standard medium and nutrient broth medium was slightly increased compared to that of the control group without 
biotreatment, but the microbial cement slurry with dairy wastewater was decreased in Table 3. Meanwhile, the thickening time of microbial cement slurry with dairy wastewater and standard medium was significantly shortened at 30Bc and 100Bc respectively; therefore, the right-angle thickening property was very important for the efficiency of cement slurry. Nevertheless, the thickening time of microbial cement slurry with nutrient broth was prolonged, and it had a negative impact on the rheology of cement slurry. It can be inferred that the fluidity of microbial cement slurry with dairy wastewater was reduced because the thickening property was improved compared to that of the control. The thickening time of G-class cement slurry in the wellbore was too long to form enough strength, and it might harm the ability of cement sheath to resist channeling outside the casing pipe.

Table 3. Rheology property of microbial cement slurry.

\begin{tabular}{cccccc}
\hline Medium & Slump/cm & $\mathbf{t}_{\mathbf{3 0 B} \mathbf{c}} / \mathbf{m i n}$ & $\mathbf{t}_{\mathbf{1 0 0 B} \mathbf{c}} / \mathbf{m i n}$ & $\mathbf{F L} / \mathbf{m L}$ & $\mathbf{S P N}$ \\
\hline SM & 21 & 258 & 268 & 28 & 1.58 \\
NB & 22 & 261 & 274 & 30 & 2.18 \\
DW & 19 & 252 & 259 & 22 & 0.88 \\
C & 20 & 259 & 269 & 24 & 1.35 \\
\hline
\end{tabular}

Moreover, the API fluid loss of microbial cement slurry with standard medium and nutrient broth medium was increased, while the microbial cement slurry with dairy wastewater was slightly decreased compared to that of the control. As is well known, this is unfavorable to the quality of cementing, as excessive API fluid loss causes serious leakage of cement slurry in the formation near the wellbore, resulting in huge economic losses. The SPN values of microbial cement slurry mixed with three kinds of media separately were all in the range of $0 \sim 3$, which showed perfect anti-gas channeling performance, especially the specimens with dairy water. It can be concluded that the dairy wastewater incubated with this mutated bacterium has a positive effect on the rheology of the cement slurry.

\subsection{Mechanical Strength of Microbial Cement Stone}

We found that the compressive strength and flexural strength of microbial cement stone were higher than those of the control due to the precipitations formed by bacteria in cement stone, as shown in Figure 5a,b. There was a difference between microbial cement slurry with dairy wastewater and the other two media. The early compressive strength and flexural strength of microbial cement stone with dairy wastewater were increased by $10.14 \%$ and $11.81 \%$, respectively, compared to those of the control after curing for 3 days. As shown in Figure 3a, the growth of bacteria in the three media was similar, and the carbonate content hydrolyzed by urea was consistent; however, the carbonate from protein in dairy wastewater was much higher than that in the other mediums. Additionally, there was a large amount of calcium that was not contained in the other media. Therefore, due to the protein and initial calcium content in dairy wastewater, the mechanical strength of microbial cement stone with dairy wastewater was higher than the other two groups with the other two media, respectively. Additionally, the mechanical strength of microbial cement stone with the curing age was studied. We found that the mechanical strength of all groups was increased with time. After curing for 7 and 28 days, the mechanical strength was improved compared to the early strength at 3 days. The compressive strength and flexural strength of microbial cement stones were higher than those of the control at 28 days. Therefore, the high mechanical strength indicates the better durability of microbial cement stone in an extreme environment.

The results showed that dairy wastewater could be an alternative medium to cultivate bacteria and exhibited a much higher efficiency of calcium carbonate precipitations. The mechanical strength of microbial cement was significantly improved, and it was beneficial for improving the resistance of fluid erosion under extreme conditions. 

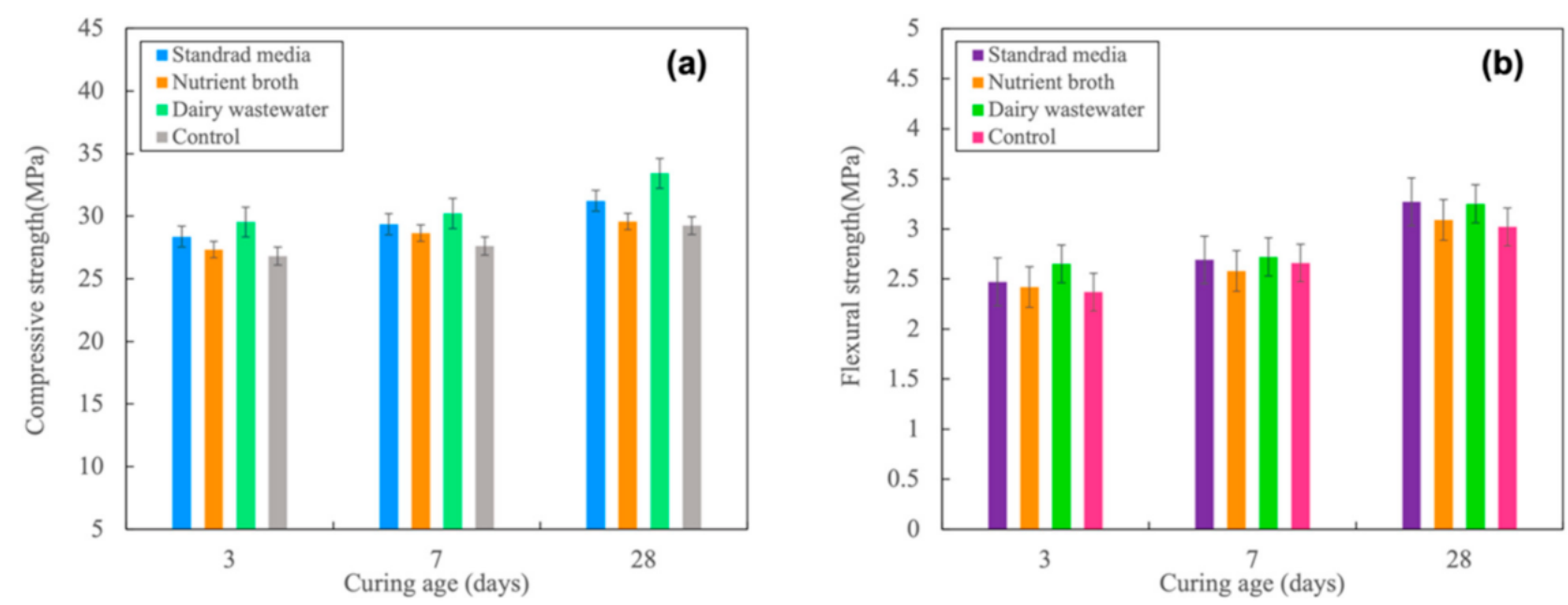

Figure 5. (a) Changes of compressive strength of microbial cement stones with curing age; (b) changes of flexural strength of microbial cement stones with curing age.

\subsection{Permeability and Porosity of Microbial Cement Stone}

We can see from Figure 6a that the permeability of microbial cement stone mixed with standard medium, nutrient broth media, and dairy wastewater was reduced by $70 \%, 25 \%$, and $90 \%$, respectively, compared with that of the control group after curing for 3 days. The permeability of all the groups was reduced with curing age. The permeability of microbial cement stone with dairy wastewater was even reduced by one to three orders of magnitude after curing for 28 days. It can be seen from Figure $6 a$ that the permeability of microbial cement stone with various media was reduced to different degrees due to the different efficiency of precipitations of calcium carbonate induced by bacteria. Additionally, the porosity of microbial cement stone mixed with standard medium, nutrient broth media, and dairy wastewater was decreased by $68.33 \%, 67.33 \%$, and $70.21 \%$, respectively, compared with that of the control after curing for 3 days, as shown in Figure 6b. It was obvious that the porosity of three groups of microbial cement stones was reduced beyond $50 \%$ compared to that of the control, and the porosity of cement stone was reduced with time due to the hydration development and microbially induced calcium precipitation in the internal micropores of cement stones. Therefore, it can be inferred that the MICP has a positive effect on the compactness of cement stones.
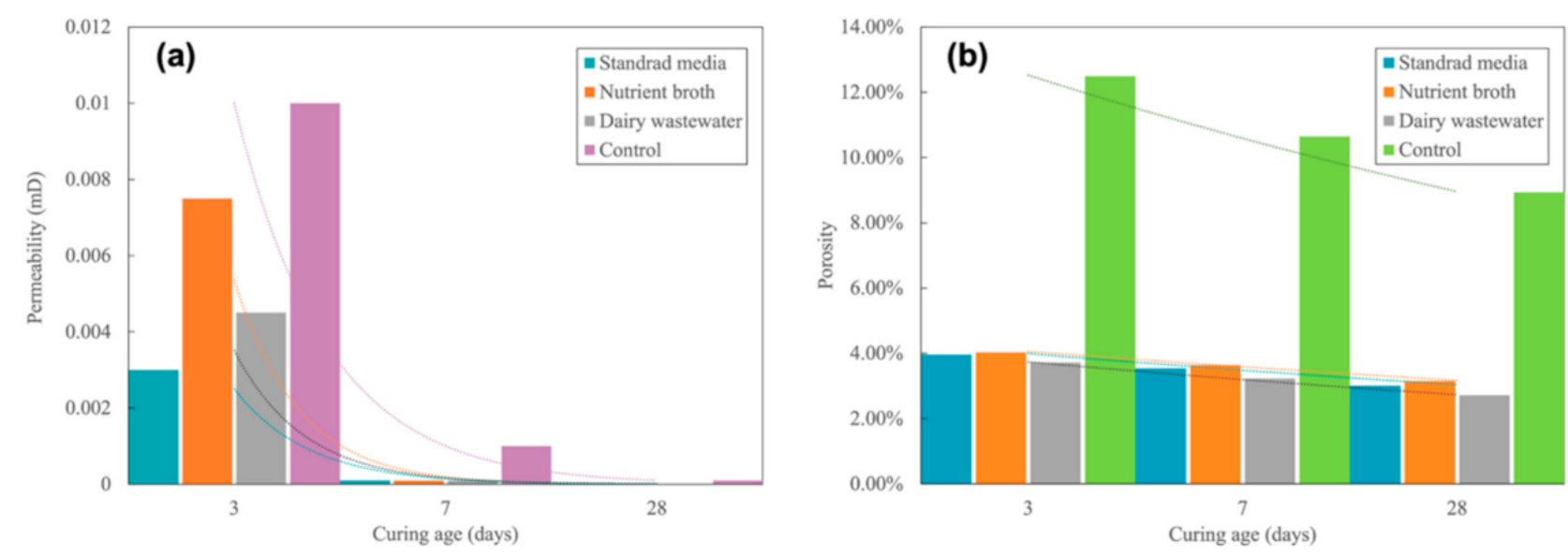

Figure 6. (a) Changes of permeability of microbial cement stone with curing age; (b) changes of porosity of microbial cement stone with curing age. 


\subsection{Viability of Bacteria in Cement Slurry}

Figure 7 displays the number of viable cells decreased with increasing curing age. The bacteria kept a high survival rate in the first $24 \mathrm{~h}$; however, after curing for 3 days, only $10 \%$ of viable microorganisms survived. The number of viable cells in the cement stone after curing for 135 days was below the MPN detection limit $\left(<\left(5 \times 10^{2}\right) \mathrm{cm}^{3}\right)$. This was consistent with the results of Jonker's experiments $[33,34,39,40]$. However, the number of bacteria that survived in this extreme condition was enough to precipitate calcium carbonate and alter the internal structure of cement stone in the early stage of cementing. Based on the drilling and completion experiences on site, the cement slurry was required with high early strength and low permeability to prevent the channeling of fluids in the formation. As exhibited in Figure 7, the bacteria can maintain high activity under the extreme environment for $24 \mathrm{~h}$; therefore, they can satisfy the requirement on site. In addition, there was no obvious difference in the three kinds of media adopted in this paper. It can be proved that dairy wastewater is not harmful to the survival of bacteria in the cement slurry like the other two media.

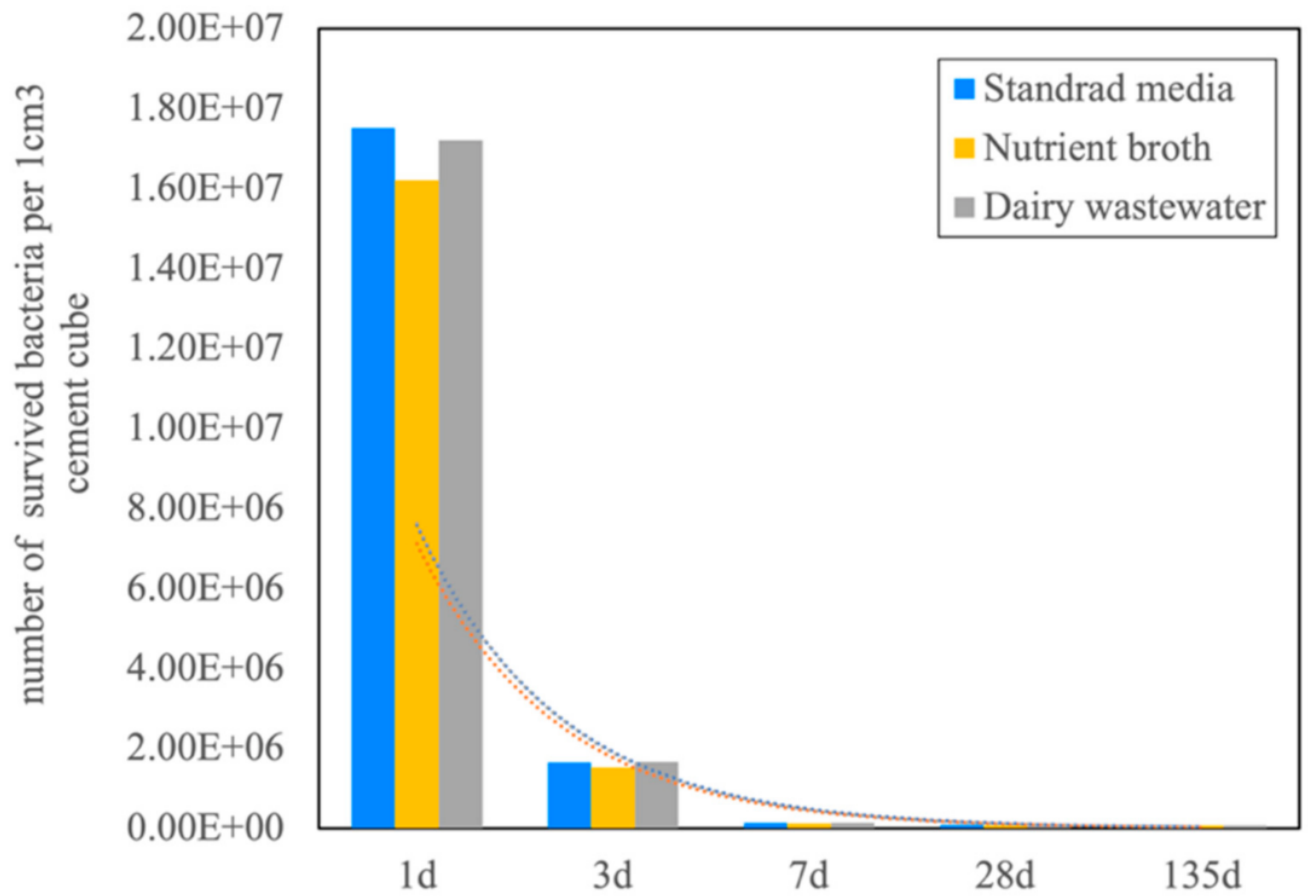

Figure 7. The number of survived bacteria in cement stones at different curing age.

\subsection{Pore Distribution of Microbial Cement Stone with Dairy Wastewater}

In this paper, we compared the microstructure of microbial cement stone with Gclass oil cement stone without biotreatment. Figure 8a shows that the pore was seriously developed and was evenly distributed in the cement stone without bacteria treatment after curing at $50{ }^{\circ} \mathrm{C}, 6.5 \mathrm{MPa}$ for 3 days, which is unfavorable to the development of the mechanical strength of cement stone. Figure $8 \mathrm{~b}$ exhibits the three-dimensional rendering of the micropores and microfractures of cement stone without biotreatment. We can see that there were numerous pores with good connectivity. Under the erosion of highpressure fluid, the pores would be easily expanded into larger cracks and fractures. The impermeability of cement stone would be reduced, and this would lead to interlayer channeling accidents or even collapse of the well borehole. In addition, it can be found that the probability distribution of the pore radius was relatively concentrated, as shown in Figure $8 \mathrm{c}$, and the pore radius was mainly in the range of 25-30 $\mu \mathrm{m}$, which indicated that the average quality of the sample was better. Additionally, the porosity of the specimen without biotreatment was $12.49 \%$, which is consistent with the results in Figure 6 . 
However, we found that the pores in the microbial cement stones with dairy wastewater were not developed in the same curing conditions, as shown in Figure 8d,e. Compared to the control group, the porosity of the microbial cement stone with dairy wastewater was significantly decreased by $70.22 \%$. There were mainly isolated pores, as shown in Figure 8e. Moreover, the connectivity was not good, which was beneficial for resisting the erosion of fluid underground. We found that the probability distribution of the pore radius was not concentrated, as shown in Figure $8 \mathrm{f}$. The pore radius was in a larger range of 8-24 $\mu \mathrm{m}$, and average pore radius of microbial cement stone with dairy wastewater was smaller than that of the control. The pore distribution was much more uniform, and the unevenness of the specimen was better compared to that of the control. The porosity of the specimen was $3.72 \%$, which is consistent with results in Figure 6. We believe that the porosity and permeability of microbial cement stones were decreased mainly due to the filling of precipitations in the micropores and microfractures. Therefore, the mechanical strength of microbial cement stones was enhanced compared with that of the control group.
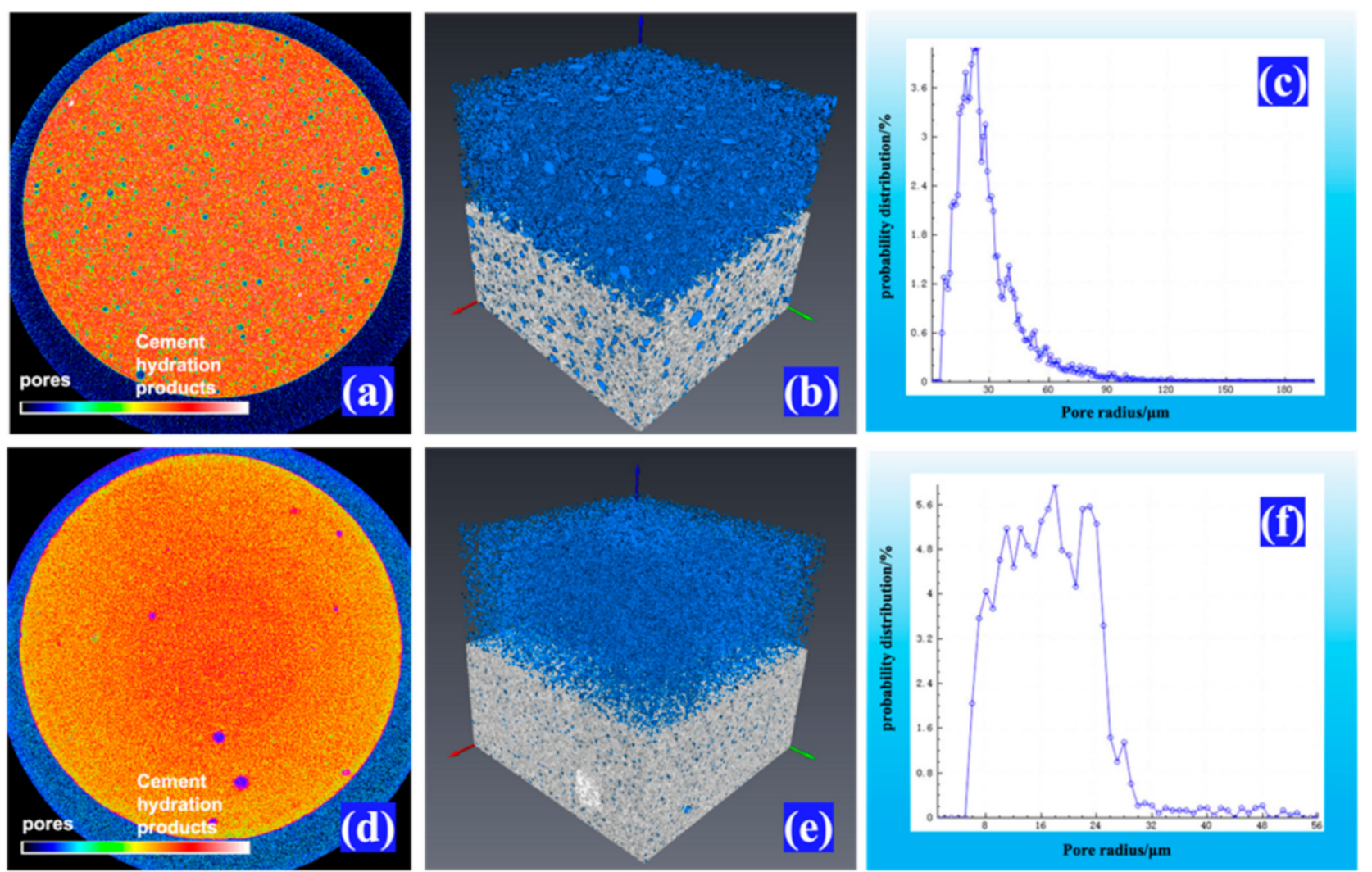

Figure 8. (a) Rendering effect of XY plane slice of cement stone without biotreatment; (b) volume rendering of internal pore threshold of G-class oil well cement stone with a size $400 \times 400 \times 400$; (c) probability distribution of pore radius of the control without biotreatment; (d) rendering effect of XY plane slice of cement stone with biotreatment; (e) volume rendering of internal pore threshold of microbial cement stone with dairy wastewater with a size $400 \times 400 \times 400$; (f) probability distribution of pore radius of microbial cement stone with dairy wastewater.

\subsection{Microstructures of Microbial Cement Stones}

It was clear that there was still a large number of micropores in the control specimens without biotreatment observed at 500 times; the dark portion is circled with a red color in Figure 9a, which was similar to the results of the CT test in Figure 8a. Nevertheless, Figure $9 \mathrm{~b}$ shows that the internal micropores of the microbial cement stone were significantly reduced, and there were rough and uneven precipitations distributed in the microbial cement stone. Additionally, we found that numerous calcium carbonate crystals circled in red were attached with a large amount of flocculent organic matter, as shown 
in Figure 9c, and these crystals were filled in the microspores and the cement hydration products of microbial cement slurry with dairy wastewater observed at 5000 times. We found that the crystals were rhombohedral, and the morphology of the crystal in microbial cement stone was the same as the morphology of precipitation in a pure environment with a liquid medium, bacteria, and calcium chloride only. As shown in Figure 9d, the precipitation was mainly calcite, and the composition of calcite was calcium carbonate. Additionally, Figure 9e shows that there were mainly calcium, carbon, and oxygen elements. Therefore, it can be inferred that the crystals with rhombohedral morphology in the hydrated calcium silicate gel were calcium carbonate induced by bacteria, as shown in Figure 9c. As we can see, calcium carbonate crystals were filled in the cement hydrated calcium silicate gel and micropores of the cement stone, thus reducing the amount and connectivity of micropores in microbial cement stone. Moreover, the surrounding calcium silicate gel was compressed to improve the compactness of cement stone, which functioned as the physical compaction. Furthermore, the crystals distributed among the cement aggregate particles strengthened the connection between precipitations and aggregates. The by-products of microbial metabolism, such as organic matter, acted as a bonding material to glue the hydration products of cement, and it was accompanied on the surface of biominerals. The biomineralized crystals showed special morphological characteristics under the joint modification of microorganisms and by-products. The spatial grid structure of cement paste was enhanced, thus contributing to the enhancement of the mechanical strength of cement stone.

Based on the distribution of crystals in cement stone, we analyzed the process of MICP in the cement slurry. The dairy wastewater, microorganisms, and calcium chloride microcapsules were added into the cement slurry first. The microcapsules and bacteria were evenly distributed in the cement slurry, as shown in Figure 10a. Subsequently, with the hydration of cement slurry, a large number of hydration products were attached to the surface of cement aggregate particles. When the hydration reached the initial setting stage, the wall of the microcapsule broke, dissolved, and released calcium chloride, as exhibited in Figure 10b. Then, the wall of encapsulation was completely dissolved, and the calcium ions transported into the surrounding cement matrix and combined with the surrounding carbonate ions due to the migration of free water in cement stone and the mutual attraction of ions with positive and negative charges, resulting in calcium carbonate precipitation in cement slurry, as shown in Figure 10c. In addition, with the metabolism of bacteria in the cement, an increasing number of by-products were produced and attached to the surface of hydration products and calcium carbonate at the same time. Due to the random distribution of dairy wastewater and calcium chloride encapsulation, the by-products and calcium carbonate were evenly distributed in the cement stone. Figure 10c shows that the calcium carbonate was embedded in cement hydration products, such as calcium silicate gel. Moreover, calcium carbonate was filled in the micropores of the cement stone. Meanwhile, by-products produced by bacteria were attached to the surface of mineralized precipitations and cement hydration products, and this served as a bridge between cement hydration products and microbial mineralization precipitation; hence, the internal microstructure was remediated in the end.

\subsection{On-Site Application of Microbial Cement Slurry with Dairy Wastewater}

To determine the feasibility of microbial cement slurry with dairy wastewater in the field, we applied it on site in the Chunguang 17-14 oil well. It can be seen from Figure 11 that the production time was cut down from 24 to $12 \mathrm{~h}$, the productivity efficiency of the field was reduced, and the daily fluid output and water content were increased due to the problem of channeling oil and water outside the casing pipe on 7 September 2019. Therefore, the workload and cost for the separation of oil and water on site were increased. Additionally, the daily oil output was sharply decreased because of the channeling outside the casing pipe. Moreover, the oil outlet flow temperature was reduced by the water. This was harmful to the recovery of heavy oil in the Chunguang 17-14 well. However, 
we applied the microbial cement slurry with dairy wastewater in the same section of the wellbore in the Chunguang 17-14 oil field on 25 November 2019. Then, we found that the problem of channeling was solved based on the data of the neutron logging test on site on 15 June 2020, as shown in Figure 12, and there was no channeling outside the casing pipe in the depth of 960-1004 $\mathrm{m}$ in the Chunguang 17-14 well after the microbial sealing operation. As exhibited in Figure 11 from 15 June 2020, the water content was cut down to $42-55 \%$, which reduced the workload of the oil-water separation. The daily fluid output and daily oil output were kept at a stable level after the sealing channeling operation. Meanwhile, the oil outlet flow temperature was improved due to the reduction in water output. Moreover, the production time every day was prolonged after the sealing channeling operation, and the efficiency of production was also improved. We can confirm that the application of microbial cement slurry with dairy wastewater under this extreme underground environment was valid.
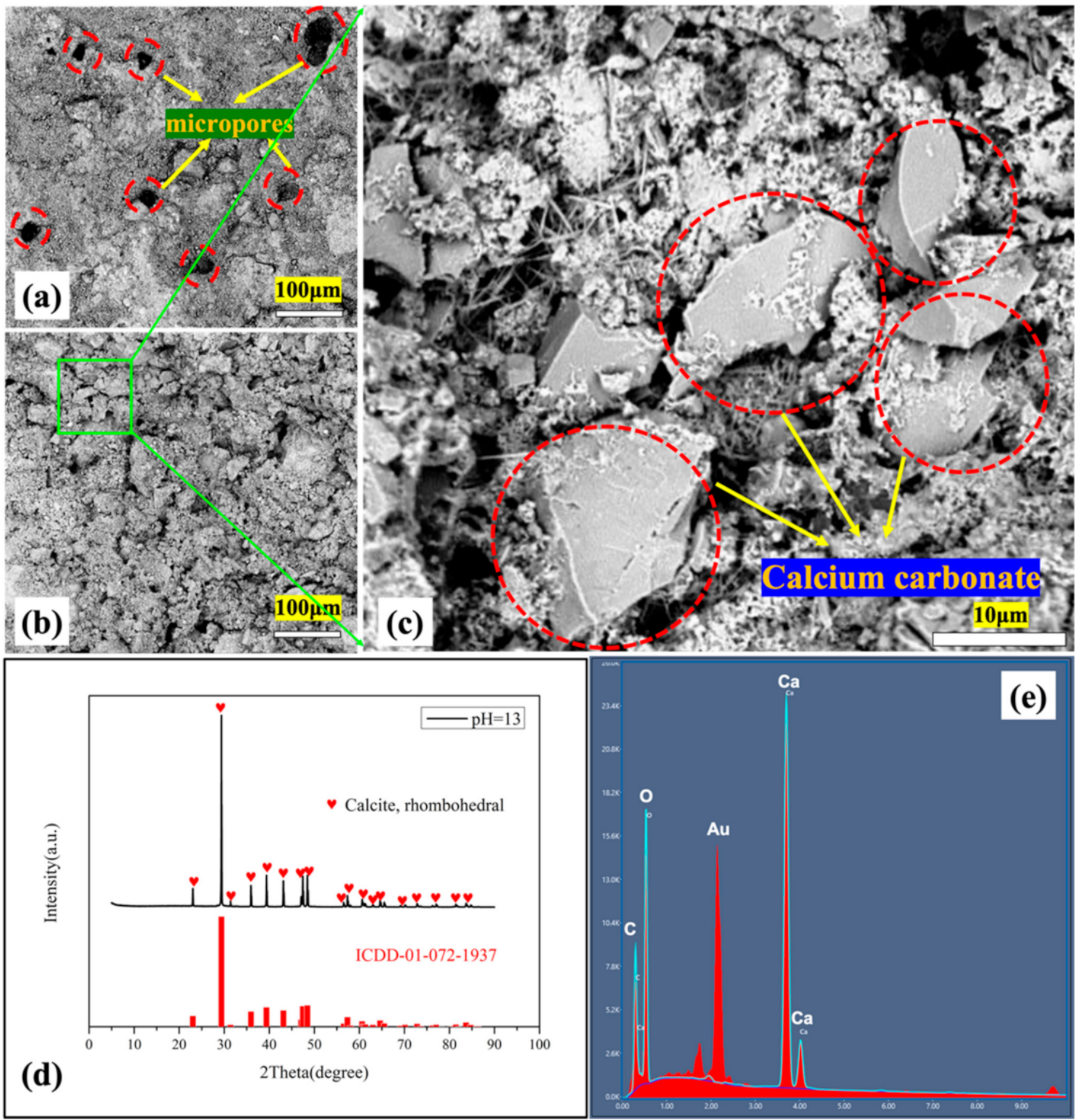

Figure 9. (a) Microstructure of the cement stone without biotreatment was observed at 500 times; (b) microstructure of the cement stone with biotreatment was observed at 500 times; (c) morphology of crystals in the cement stones with microbially induced calcium carbonate precipitation (MICP) treatment was observed at 5000 times; (d) XRD test of the precipitations in medium; (e) Energy Dispersive Spectrometer (EDS) test of the crystals in cement stones. 


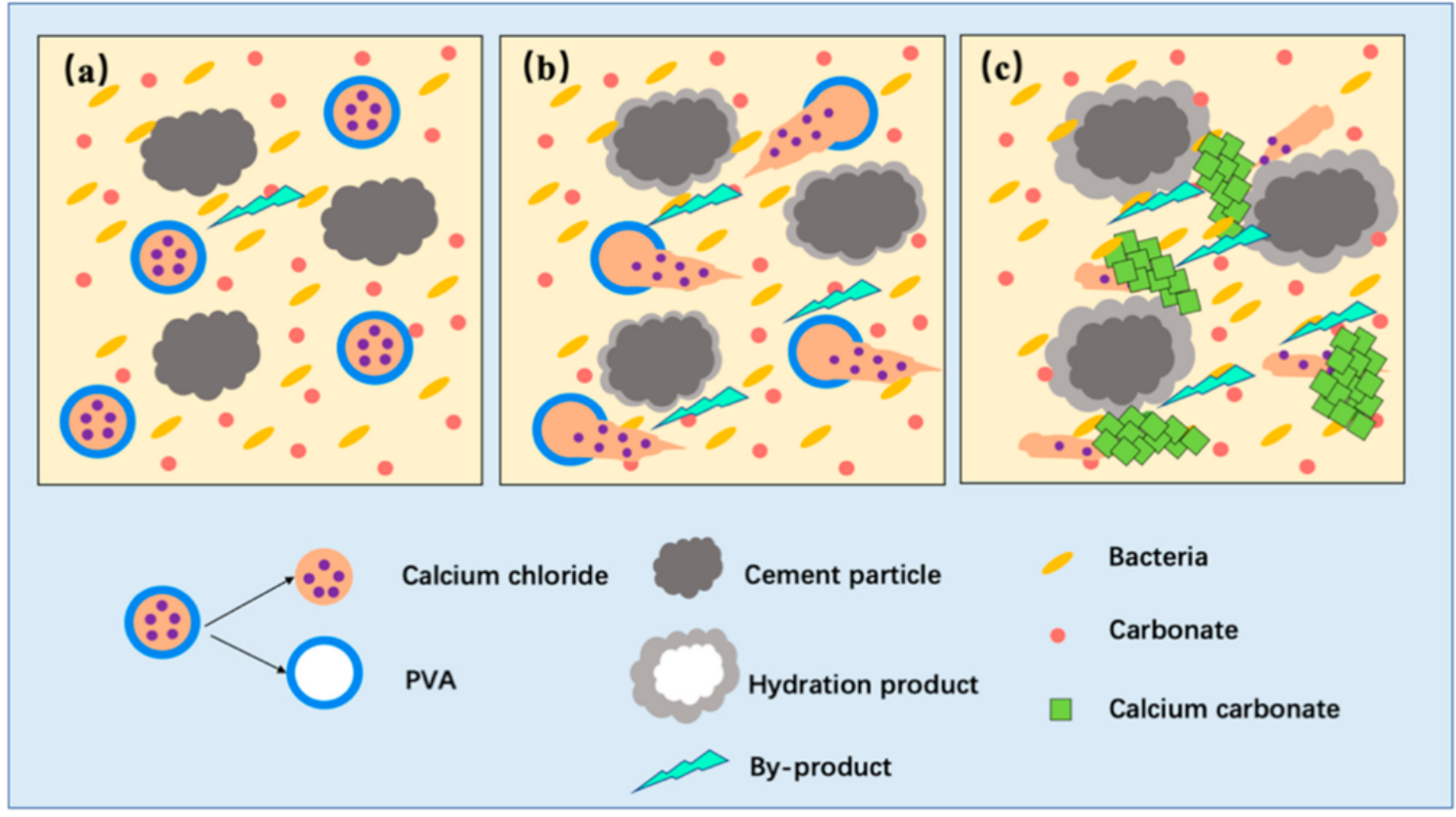

Figure 10. (a) The distribution of matrixes in cement slurry in the initial stage; (b) the microcapsule was broken, and the calcium chloride was released into the cement slurry; (c) the microbially induced calcium carbonate precipitation in the cement slurry.
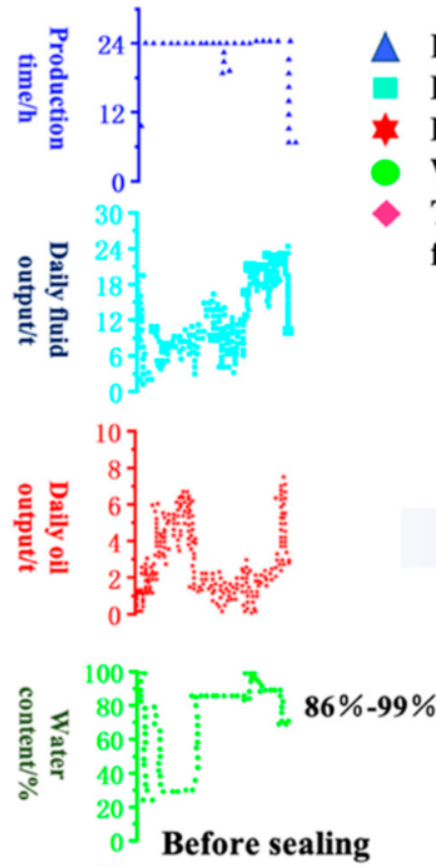

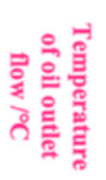

${ }^{50}$ ] channeling

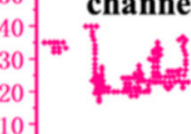

Production time

Daily fluid output

Daily oil output

Water content

Temperature of oil outlet

flow
Sealing channeling operation

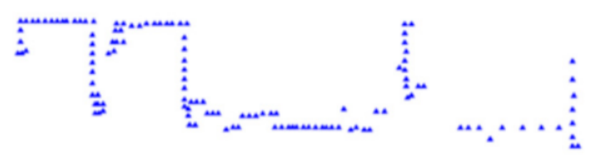

$\vdots \vdots \vdots ;$

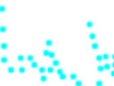

\section{After sealing \\ channeling}
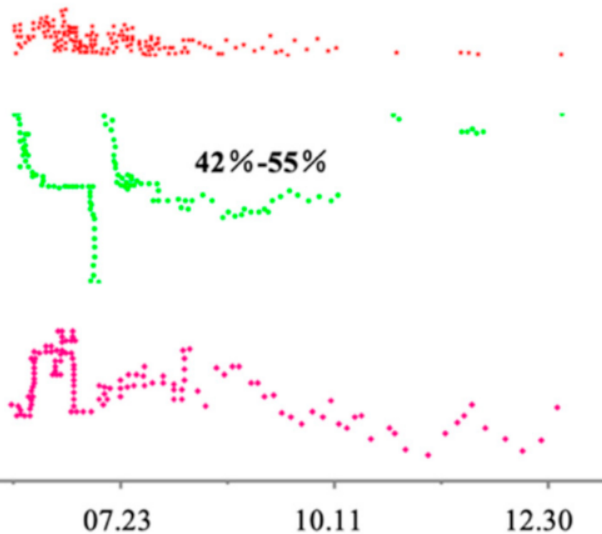

Figure 11. Changes of production parameters of Chunguang 17-14 well after treatment with microbial cement slurry. 


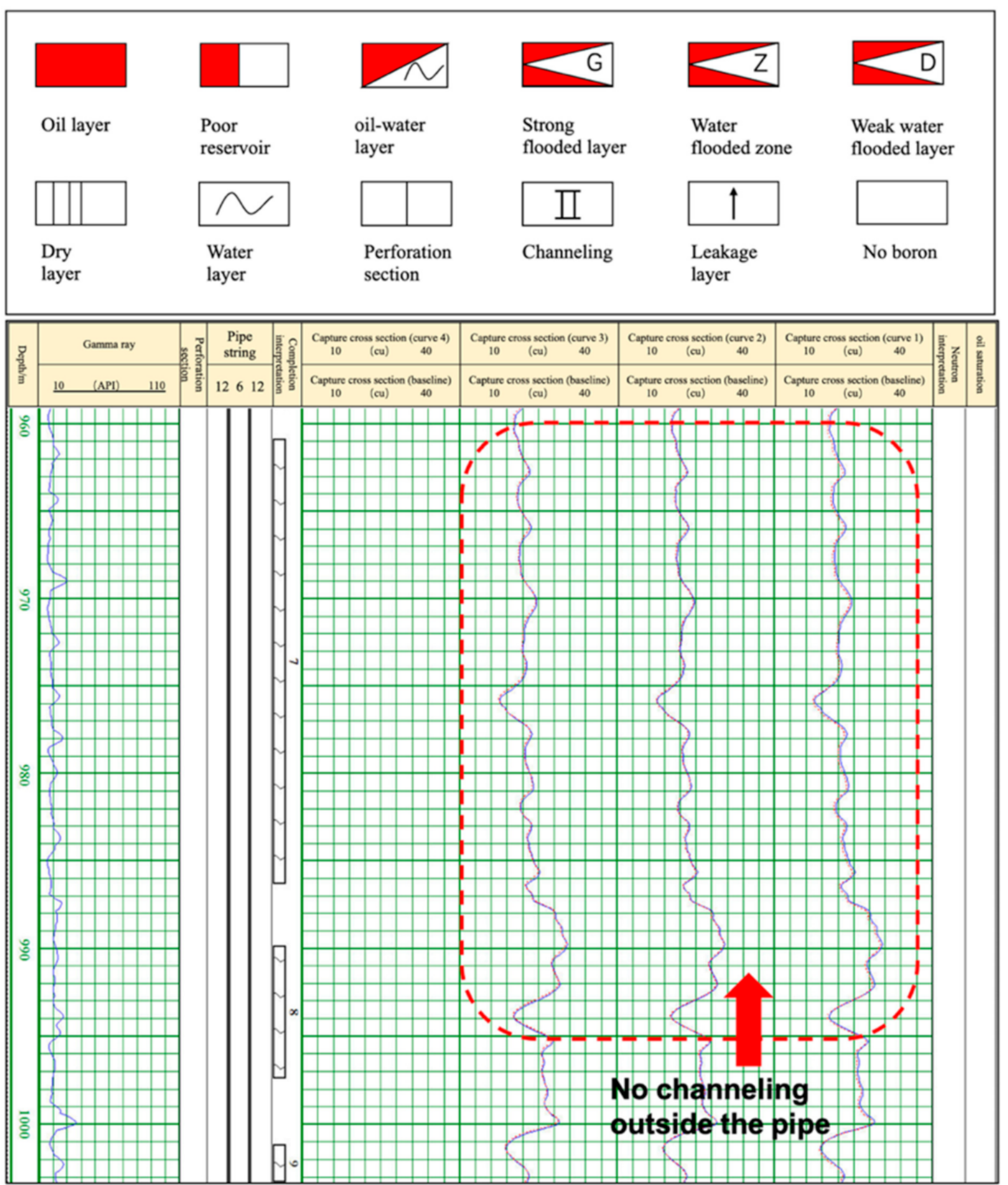

Figure 12. Neutron logging in Chunguang 17-14 well after biosealing.

Additionally, we also compared this technology with the second injection of cement slurry in the well next to the Chunguang 17-14 well. We found that the method of the second injection of $\mathrm{G}$ class oil cement slurry would cause plugging, resulting in the failure of cementation according to previous experience. Moreover, the cost of secondary injection of G class oil cement slurry in the Chunguang 17-10 well next to the Chunguang 17-14 well was much higher than the microbial cement slurry. We found that the Chunguang 17-14 well was well healed; nevertheless, there was still a channeling problem after injecting the $\mathrm{G}$ class oil cement in the Chunguang 17-10 well again with the same volume of 
microbial cement slurry. Thus, this indicates the higher efficiency of microbial cement slurry compared to that of conventional technologies. In addition, we tested the elements of unground water in the same bearing formation in the field. We did not find that there was anything strange after applying the microbial cement slurry in the well. Therefore, this indicates that the microbial cement slurry with dairy wastewater would not cause pollution to the underground water.

\title{
4. Conclusions
}

It can be concluded that dairy wastewater can be used as an alternative medium to cultivate the mutated bacteria under extreme conditions. Additionally, the microbial cement slurry mixed with dairy wastewater showed a better rheology performance, higher mechanical strength, and lower porosity and permeability compared to the $G$ class oil cement slurry. Moreover, due to the filling of calcium carbonate crystals and the flocculent by-products produced by microorganisms in the micropores of the cement stone, the compactness was significantly improved. Moreover, not only the water content was reduced, but also the production time was prolonged after microbial cement slurry was applied in the well on site. The channeling problem underground was solved, and the efficiency of oil production was also improved. The fact that the microbial cement slurry with dairy wastewater was successfully applied in the Chunguang 17-14 indicates a bright prospect of bioremediation in extreme underground conditions.

Author Contributions: Conceptualization, T.L.; methodology, T.L. and L.L.; software, J.S.; validation, L.L. and S.Z.; formal analysis, L.L. and J.S.; investigation, L.L., S.Z. and H.L.; resources, G.J.; data curation, J.S. and E.L.; writing-original draft preparation, L.L.; writing—review and editing, L.L., C.F. and V.M.; visualization, L.L.; supervision, T.L., G.J. and N.N.; project administration, G.J. and N.N.; funding acquisition, G.J. and N.N. All authors have read and agreed to the published version of the manuscript.

Funding: This research was funded by National Key R\&D Program of China, grant number 2016YFE0204300, and National Natural Science Foundation of China, grant number 42072343.

Institutional Review Board Statement: Not applicable.

Informed Consent Statement: Not applicable.

Data Availability Statement: Not applicable.

Acknowledgments: We thank Saint Petersburg Mining University for technical support.

Conflicts of Interest: The authors declare no conflict of interest.

\author{
Abbreviations \\ MICP Microbially Induced Calcium Carbonate Precipitations. \\ SM Standard Medium. \\ NB Nutrient Broth. \\ DW Dairy Wastewater. \\ C Control group. \\ G G class oil well cement slurry. \\ $\mathrm{T}$ Temperature. \\ P Pressure. \\ COD Chemical Oxygen Demand. \\ BOD Biochemical oxygen demand. \\ OD Optical Density. \\ $\mathrm{BC} \quad$ Cement thickness unit \\ $\mathrm{t} 30 \mathrm{Bc}$ thickening time at 30Bc. \\ $\mathrm{t} 100 \mathrm{Bc}$ thickening time at $100 \mathrm{Bc}$. \\ FL Fluid Loss, mL. \\ SPN Cement Slurry Performance Numeric. \\ FTIR Fourier Transform Infrared Spectroscopy.
}


PVA Polyvinyl Alcohol.

CT Computed Tomography.

XRD X-ray Diffraction.

SEM Scanning Electron Microscope.

EDS Energy Dispersive Spectrometer.

\section{References}

1. Jayashree, S.; Ramesh, S.T.; Lavanya, A.; Gandhimathi, R.; Nidheesh, P.V. Wastewater Treatment by Microbial Fuel Cell Coupled with Peroxicoagulation Process. Clean Technol. Environ. Policy 2019, 21, 2033-2045. [CrossRef]

2. Mansoorian, H.J.; Mahvi, A.H.; Jafari, A.J.; Khanjani, N. Evaluation of Dairy Industry Wastewater Treatment and Simultaneous Bioelectricity Generation in a Catalyst-Less and Mediator-Less Membrane Microbial Fuel Cell. J. Saudi Chem. Soc. 2016, 20, 88-100. [CrossRef]

3. Arnon, S.; Dahan, O.; Elhanany, S.; Cohen, K.; Pankratov, I.; Gross, A.; Ronen, Z.; Baram, S.; Shore, L.S. Transport of Testosterone and Estrogen from Dairy-Farm Waste Lagoons to Groundwater. Environ. Sci. Technol. 2008, 42, 5521-5526. [CrossRef] [PubMed]

4. Zheng, W.; Yates, S.R.; Bradford, S.A. Analysis of Steroid Hormones in a Typical Dairy Waste Disposal System. Environ. Sci. Technol. 2008, 42, 530-535. [CrossRef] [PubMed]

5. Pilegis, M.; Davies, R.; Lark, R.; Gardner, D.; Jefferson, A. Challenges of self-healing concrete scale-up and site trials. In Proceedings of the 9th International Conference on Fracture Mechanics of Concrete and Concrete Structures, Berkeley, CA, USA, 28 May-1 June 2016.

6. Silva, F.; Boon, N.; Belie, N.; Verstraete, W. Industrial Application of Biological Self-Healing Concrete: Challenges and Economical Feasibility. J. Commer. Biotechnol. 2015, 21, 31-38. [CrossRef]

7. Van Vliet, K.; Pellenq, R.; Buehler, M.J.; Grossman, J.C.; Jennings, H.; Ulm, F.-J.; Yip, S. Set in Stone? A Perspective on the Concrete Sustainability Challenge. MRS Bull. 2012, 37, 395-402. [CrossRef]

8. William Carey, J.; Svec, R.; Grigg, R.; Lichtner, P.C.; Zhang, J.; Crow, W. Wellbore Integrity and CO2-Brine Flow along the Casing-Cement Microannulus. Energy Procedia 2009, 1, 3609-3615. [CrossRef]

9. Coffer, H.F.; Reynolds, J.J.; Clark, R.C. A Ten-Pound Cement Slurry for Oil Wells. J. Pet. Technol. 1954, 6, 35-37. [CrossRef]

10. Bolhuis, P.; Gee, A.D.; Feilzer, A. The Influence of Fatigue Loading on the Quality of the Cement Layer and Retention Strength of Carbon Fiber Post-Resin Composite Core Restorations. Oper. Dent. 2005, 30, 220-227.

11. Broni-Bediako, E.; Joel, O.; Ofori-Sarpong, G. Oil Well Cement Additives: A Review of the Common Types. Oil Gas Res. 2016, 2. [CrossRef]

12. Soares, L.W.O.; Braga, R.M.; Freitas, J.C.O.; Ventura, R.A.; Pereira, D.S.S.; Melo, D.M.A. The Effect of Rice Husk Ash as Pozzolan in Addition to Cement Portland Class G for Oil Well Cementing. J. Pet. Sci. Eng. 2015, 131, 80-85. [CrossRef]

13. Allwood, J.M.; Cullen, J.M.; Milford, R.L. Options for Achieving a 50\% Cut in Industrial Carbon Emissions by 2050. Environ. Sci. Technol. 2010, 44, 1888-1894. [CrossRef] [PubMed]

14. Dick, J.; De Windt, W.; De Graef, B.; Saveyn, H.; Van der Meeren, P.; De Belie, N.; Verstraete, W. Bio-Deposition of a Calcium Carbonate Layer on Degraded Limestone by Bacillus Species. Biodegradation 2006, 17, 357-367. [CrossRef]

15. Hammes, F.; Boon, N.; De Villiers, J.; Verstraete, W.; Siciliano, S.D. Strain-Specific Ureolytic Microbial Calcium Carbonate Precipitation. Appl. Environ. Microbiol. 2003, 69, 4901-4909. [CrossRef]

16. Akiyama, M.; Kawasaki, S. Microbially Mediated Sand Solidification Using Calcium Phosphate Compounds. Eng. Geol. 2012, 137-138, 29-39. [CrossRef]

17. Dejong, J.; Soga, K.; Kavazanjian, E.; Burns, S.; Van Paassen, L.; Al Qabany, A.; Aydilek, A.; BANG, S.S.; Burbank, M.; Caslake, L.; et al. Biogeochemical Processes and Geotechnical Applications: Progress, Opportunities and Challenges. Géotechnique 2013, 63, 287-301. [CrossRef]

18. Salifu, E.; MacLachlan, E.; Iyer, K.R.; Knapp, C.W.; Tarantino, A. Application of Microbially Induced Calcite Precipitation in Erosion Mitigation and Stabilisation of Sandy Soil Foreshore Slopes: A Preliminary Investigation. Eng. Geol. 2016, 201 , 96-105. [CrossRef]

19. Wu, C.; Chu, J.; Shifan, W.; Hong, Y. 3D Characterization of Microbially Induced Carbonate Precipitation in Rock Fracture and the Resulted Permeability Reduction. Eng. Geol. 2018, 249. [CrossRef]

20. Bang, S.S.; Galinat, J.K.; Ramakrishnan, V. Calcite Precipitation Induced by Polyurethane-Immobilized Bacillus Pasteurii. Enzyme Microb. Technol. 2001, 28, 404-409. [CrossRef]

21. Ghosh, P.; Mandal, S.; Chattopadhyay, B.D.; Pal, S. Use of Microorganism to Improve the Strength of Cement Mortar. Cem. Concr. Res. 2005, 35, 1980-1983. [CrossRef]

22. Belie, N.; Gruyaert, E.; Al-Tabbaa, A.; Antonaci, P.; Baera, C.; Bajare, D.; Darquennes, A.; Davies, R.; Ferrara, L.; Jefferson, A.; et al. A Review of Self-Healing Concrete for Damage Management of Structures. Adv. Mater. Interfaces 2018. [CrossRef]

23. Belie, N.; Muynck, W. Crack Repair in Concrete Using Biodeposition; CRC Press/Balkema: Boca Raton, FL, USA, 2008 ; pp. 777-781. [CrossRef]

24. Van Tittelboom, K.; De Belie, N.; Van Loo, D.; Jacobs, P. Self-Healing Efficiency of Cementitious Materials Containing Tubular Capsules Filled with Healing Agent. Cem. Concr. Compos. 2011, 33, 497-505. [CrossRef] 
25. Achal, V.; Mukherjee, A.; Reddy, M. Effect of Calcifying Bacteria on Permeation Properties of Concrete Structures. J. Ind. Microbiol. Biotechnol. 2010, 38, 1229-1234. [CrossRef] [PubMed]

26. Achal, V.; Mukherjee, A.; Goyal, S.; Reddy, M. Corrosion Prevention of Reinforced Concrete with Microbial Calcite Precipitation. ACI Mater. J. 2012, 109, 157-164.

27. Achal, V.; Mukerjee, A.; Reddy, M. Biogenic Treatment Improves the Durability and Remediates the Cracks of Concrete Structures. Constr. Build. Mater. 2013, 48, 1-5. [CrossRef]

28. Achal, V.; Mukherjee, A.; Kumari, D.; Zhang, Q. Biomineralization for Sustainable Construction-A Review of Processes and Applications. Earth-Sci. Rev. 2015, 148. [CrossRef]

29. Achal, V.; Mukherjee, A.; Basu, P.C.; Reddy, M. Lactose Mother Liquor as an Alternative Nutrient Source for Microbial Concrete Production by Sporosarcina Pasteurii. J. Ind. Microbiol. Biotechnol. 2009, 36, 433-438. [CrossRef]

30. Achal, V.; Mukherjee, A.; Reddy, M. Microbial Concrete: A Way to Enhance the Durability of Building Structures. J. Mater. Civ. Eng. J MATER Civ. ENG 2010, 23. [CrossRef]

31. Achal, V.; Mukherjee, A.; Reddy, M. ORIGINAL RESEARCH: Biocalcification by Sporosarcina Pasteurii Using Corn Steep Liquor as the Nutrient Source. Ind. Biotechnol. 2010, 6, 170-174. [CrossRef]

32. Achal, V.; Mukherjee, A.; Basu, P.C.; Reddy, M.S. Strain Improvement of Sporosarcina Pasteurii for Enhanced Urease and Calcite Production. J. Ind. Microbiol. Biotechnol. 2009, 36, 981-988. [CrossRef] [PubMed]

33. Jonkers, H.M. Development and application of bacteria-Based self-healing materials. In Proceedings of the 40th ICT Convention/Symposium, Warwickshire, UK, 22 March 2012.

34. Jonkers, H.M.; Schlangen, E. Crack repair by concrete-immobilized bacteria. Civ. Eng. 2007, 7, 1-7.

35. Phillips, A.; Cunningham, A.; Gerlach, R.; Hiebert, R.; Hwang, C.; Lomans, B.; Westrich, J.; Mantilla, C.; Kirksey, J.; Esposito, R.; et al. Fracture Sealing with Microbially-Induced Calcium Carbonate Precipitation: A Field Study. Environ. Sci. Technol. 2016, 50. [CrossRef] [PubMed]

36. Kirkland, C.M.; Zanetti, S.; Grunewald, E.; Walsh, D.O.; Codd, S.L.; Phillips, A.J. Detecting Microbially Induced Calcite Precipitation in a Model Well-Bore Using Downhole Low-Field NMR. Environ. Sci. Technol. 2017, 51, 1537-1543. [CrossRef]

37. Whiffin, V. Microbial CaCO3 Precipitation; VDM Verlag Dr. Mller Aktiengesellschaft \& Co. KG: Berlin, Germany, 2008; ISBN 978-3-639-03872-9.

38. Clarke, K.R.; Owens, N.J.P. A Simple and Versatile Micro-Computer Program for the Determination of 'Most Probable Number'. J. Microbiol. Methods 1983, 1, 133-137. [CrossRef]

39. Jonkers, H.M. Self Healing Concrete: A Biological Approach. In Self Healing Materials; Van der Zwaag, S., Ed.; Springer: Dordrecht, The Netherlands, 2007; pp. 195-204. ISBN 978-1-6714020-6249-0.

40. Sierra-Beltran, L.; Jonkers, H.M. Crack Self-Healing Technology Based on Bacteria. J. Ceram. Process. Res. 2015, 16, s33-s39. 